\title{
Auditory Neuropathy の診断と治療
}

\author{
東北大学大学院医工学研究科 /医学系研究科 聴覚・言語障害学分野 \\ 川瀬 哲 明
}

Auditory Neuropathy (AN) または Auditory Nerve Disease は, (1) 聴カレベルに比して極端に不良な語音明瞭 度，(2) 正常に保たれた外有毛細胞機能（耳音響放射 (OAE : otoacoustic emission)，または蝸牛マイクロフ オン電位 (CM : cochlear microphonics) の検出), (3) 極めて高度に障害された（しばしば無反応）聴性脳幹反 応 (ABR: auditory brainstem response) などの所見を 特徴とする感音難聴である. 1996年に Kaga ら ${ }^{1)}$, Starr $ら^{2)}$ により新しい疾患概念として報告された。内有毛細 胞, 内有毛細胞と蝸牛神経のシナプス，あるいは，螖牛 神経の障害に起因するさまざまな病態を内包する.

一方, 近年 Auditory Neuropathy Spectrum Disorder (ANSD) という概念が提唱されているが，AN はANSD を呈する一病態であるが，同義ではない（ANSD は新生 児スクリーニングやその後の精査で，ABR不良，OAE 正常を呈した場合に診断されるが，ANのほか，その後 ABR が正常化する病態，難聴が進行し OAE が消失する 病態などさまざまな病態を含む) ${ }^{3)}$.

\section{1. 原因・病態}

AN の原因は多様である，新生児期の高ビリルビン血 症や低酸素症のほか, OPA1 遺伝子や OTOF 遺伝子な どさまざまな責任遺伝子が明らかにされている3) 6)。一 方，ANには多彩な病理が含まれるが，螖牛神経のスパ イク情報に同期障害（dys-synchrony）などの異常が生 じていることが，共通する主な病態生理として考えられ ている，すなわち，音入力により蝸牛神経のスパイク数 が増加すれば音の検知はなされるが，スパイクの発火に 同期不良などの異常があるために，語音明瞭度の不良や $\mathrm{ABR}$ 波形の消失が生じると考えられている。一方，原 則, 外有毛細胞機能は正常であり, 外有毛細胞が関与す る蝸牛の “active process”には異常を認めない。

\section{2. 診断のポイント}

純音聴力検査では, 低音障害型感音難聴の聴力像を呈 する場合が少なくないとされるが，実際には，さまざま
なレベル, 型の難聴が存在しえる。聴力像のみから確定 診断を行うことは難しい. 聴力レベルに比して，会話の 聞き取り不良の訴えが強いことは，本症を疑うきっかけ になるが，感音難聴の鑑別診断として本症を念頭にお き, (1) 語音聴力検査, (2) $\mathrm{OAE}$ 検査, (3) $\mathrm{ABR}$ 検査に より，聴カレベルに比して極端に不良な語音明瞭度，正 常な外有毛細胞機能, ABRの無反応を確認することが 重要となる，ABRをすぐに実施できない場合は，音響 性アブミ骨筇反射（SR：stapedius reflex）検查も有用 である. AN では聴力閾值の上昇が比較的軽度であって も，しばしば SRの欠如を認める。一方，ABRは消失し ても，N1 などの聴性緩反応は記録されうることが知ら れている7 . N1 の反応検出の有無と語音明瞭度の障害 程度には一定の相関があるとされており ${ }^{8}, \mathrm{~N} 1$ 反応の 有無が疾患重症度を反映する可能性も指摘されてい $ろ^{778)}$.

このほか, 診断が確定した後, 病因・病態診断や治療 方針の決定のために有用になる検查としては, (4) 蝸電 図検査, (5) 遺伝子検査が挙げられる。後述するように, 会話聴取の困難が進行した $\mathrm{AN}$ 症例では, 人工内耳の適 応が考慮されるが，人工内耳の効果は，ANの責任病変 により影響を受ける可能性がある。この点において，両 検査は有用な情報を提供することが期待される。

すなわち, 蝸電図検査では, 正常外有毛細胞機能を示 唆する正常の cochlear microphonics $(\mathrm{CM})$ を認めるが, 主に内有毛細胞（一部外有毛細胞）由来とされる summating potential(SP) やシナプス後部の excitatory postsynaptic potential(EPSP) を反映するとされる dendritic potential(DP) などの所見から内有毛細胞と螖牛神経間 のシナプスにおける障害部位（シナプス前部, 後部など） が診断可能であるとされる. また, 特定の遺伝子変異 が確認されれば，障害部位に関する情報のみならず，過 去の報告から人工内耳の効果などに関する情報を得るこ ともできる4). 


\section{3. 治療方針}

AN の根本的治療法は確立されていない，一定の閾值 上昇を伴う場合は, 補聴器が考慮されることがあるが,

一般に, 補聴器の有効性はほとんどないか, かなり限定 的であることが多い。また，騒音環境下での聴き取り困 難には難渋することが多いが，一方で，静かなところで の 1 対 1 (対面) での会話聴取は比較的可能な場合も少 なくない.

会話聴取の困難が進行した場合は，人工内耳の適応が 考慮される. OTOF 遺伝子の変異による ANでは, 内有 毛細胞一蝸牛神経シナプスのシナプス前部に障害の主体 があるとされるため（シナプス小胞がシナプス前膜の膜 融合し神経伝達物質を放出する過程の障害), 良好な効 果が期待できる．また，視神経委縮に合併する OPA1 遺伝子変異によるANでは, シナプス後部（蝸牛神経側） 神経終末の異常が指摘されているが，人工内耳の刺激は 病変部より中枢側であるため, 螖牛神経障害ではあるが 人工内耳による言葉の聴きとり改善が期待できるとされ ている ${ }^{5)}$.一方, Charcot-Marie-Tooth disease に伴う難 聴では, 蝸牛神経などの軸索障害が指摘されているた め, 人工内耳の効果は通常の内耳性難聴に比してやや劣 る可能性があるが，術前に比して一定の効果が得られる 症例が少なくないとされている6.

\section{参考文献}

1) Kaga $K$, Nakamura M, Shinogami $M$, et al : Auditory nerve disease of both ears revealed by auditory brainstem responses, electrocochleography and otoacoustic emissions. Scand Audiol 1996 ; 25 : 233-238.

2) Starr A, Picton TW, Sininger Y, et al : Auditory neuropathy. Brain 1996 ; 119 : 741-753.
3) Kaga K: Auditory nerve disease and auditory neuropathy spectrum disorders. Auris Nasus Larynx 2016; 43 : 10-20.

4) Nishio SY, Usami SI : Outcomes of cochlear implantation for the patients with specific genetic etiologies: a systematic literature review. Acta Otolaryngol 2017; 137 : 730-742.

5) Santarelli R, Rossi R, Scimemi P, et al: OPA1-related auditory neuropathy : site of lesion and outcome of cochlear implantation. Brain 2015 ; 138 : 563-576.

6) Postelmans JT, Stokroos RJ : Cochlear implantation in a patient with deafness induced by Charcot-Marie-Tooth disease (hereditary motor and sensory neuropathies). J Laryngol Otol 2006 ; 120 : 508-510.

7) Takata Y, Kawase T, Nakasato N, et al : Auditory evoked magnetic fields in patients with absent brainstem responses due to auditory neuropathy with optic atrophy. Clin Neurophysiol 2012; 123 : 985-992.

8) Rance G, Cone-Wesson B, Wunderlich J, et al: Speech perception and cortical event related potentials in children with auditory neuropathy. Ear Hear 2002; 23 : 239-253.

9) McMahon CM, Patuzzi RB, Gibson WPR, et al : Identification of different subtypes of auditory neuropathy using electrocochleography. In Neuropathies of the auditory and vestibular eighth cranial nerves (Eds. Kaga K, Starr A, Springer) ; 2009 : pp. 21-36.

連絡先 $\bar{T} 980-8573$ 仙台市青葉区星陵町 1-1 東北大学大学院医工学研究科/医学系研究科 聴覚・言語障害学分野 川瀬哲明 